\title{
High Air Relative Humidity and Lighting Modes Govern Mould Growths on Damp Soil Ruins' Surface in High-Humidity Regions
}

\author{
Yonghui $\mathrm{Li}^{1,}$, , Weilun Zhang ${ }^{1}$, Ruobin $\mathrm{Wu}^{1}$, Xinyuan $\mathrm{Dang}^{1}$, and Shuichi $\mathrm{Hokoi}^{2}$ \\ ${ }^{1}$ School of Architecture, Southeast University, 210000 Nanjing, Jiangsu Province, P.R. China \\ ${ }^{2}$ Architecture Internationalization Demonstration School, Southeast University, 210000 Nanjing, Jiangsu Province, P.R. China
}

\begin{abstract}
Mould growth, caused by favourable hygrothermal environment like high relative humidity, proper temperature and other environmental variables, is one of the most severe hazards to soil ruins in high-humidity regions. Nevertheless, the effects of these variables on mould growth under extremely high humidity conditions remain elusive. In our previous research, samples from Wenzhou Qiaolou soil ruin were used to estimate the effects of two factors, ventilation and lighting modes, in unison. Based on that, a subsequent analysis has been conducted to assess mould growth differences with air relative humidity and lighting modes. We found that the extremely stable high-humidity environment (99.9\%) had a significantly inhibitory effect on mould growth of damp surface of soil ruins. This paper also gives suggestions on the management of soil ruin exhibition halls in high-humidity regions.
\end{abstract}

\section{Introduction}

Dispersal of fungi spores and development of their colonization pose severe damages to a large number of soil ruins in high-humidity regions, as shown in Figure 1. Although many investigations had studied the relationship between mould growth and environmental variables, current research are mainly focused on driven factors, such as temperature, relative humidity, substrate and exposure time [1,2].

A growing body of research has shown that proper temperature $\left(0-30^{\circ} \mathrm{C}\right)$ and high relative humidity $(>75 \%)$ stimulate mould growth $[3,4]$. Studies on mould growth on cultural relics, indoor settings, caves, and ancient tomb murals in damp environments are also numerous [5-9]. However, the scenario on mould growth under extremely high humidity conditions remains elusive. This situation is obvious given that most soil ruins, particularly those in hypogene environments, are exposed to a stable temperature $\left(10-15^{\circ} \mathrm{C}\right)$ and extremely high relative humidity [10].

Meanwhile, effects of other environmental factors, including ventilation and lighting modes, were also not sufficiently considered, although some studies regarding the effects of microbial communities on cultural heritages have been reported $[11,12]$.

Based on our previous studies [13,14], the ventilated and lit environment proved to be conducive to mould dispersal and colonization on the surface of damp rammed earth, especially for naturally lit environment, in high-humidity areas. However, the effects of air relative humidity (hereafter ' $\mathrm{RH}$ ') on mould growth with different lighting conditions are not clear.

Several main types of lighting modes are adopted in soil ruins exhibition halls, including sole artificial lighting, sole natural lighting, artificial lighting combined with natural lighting, and no lighting. Table 1 lists the lighting modes currently used in some typical ruins' exhibition halls. It has been proved that divergence in pigment composition of phototrophic microorganisms allows them to utilize the light energy efficiently and therefore, favours species coexistence. Thus, the influence of lighting modes on mould growth should be considered.

In this research, the Wenzhou Qiaolou soil ruin provided an ideal example to confirm our hypothesis that both air relative humidity and lighting modes govern mould growth in extremely humidity regions. This subtropical city is located in Southeastern China, with an annual temperature ranging from $2.4^{\circ} \mathrm{C}$ to $32.9^{\circ} \mathrm{C}$ (average $19.3^{\circ} \mathrm{C}$ ) and $\mathrm{RH}$ from $31 \%$ to $93 \%$ (average $70 \%$ ). Its underground level remains at $1.0-1.5 \mathrm{~m}$. Due to the rising damp in rainy seasons, increasing moisture content of rammed earth and ambient air relative humidity level, mould inevitably grow on surfaces in damp soil ruins in high-humidity regions and thus, damages the soil ruins.

\footnotetext{
* Corresponding author: liyonghui@seu.edu.cn
} 

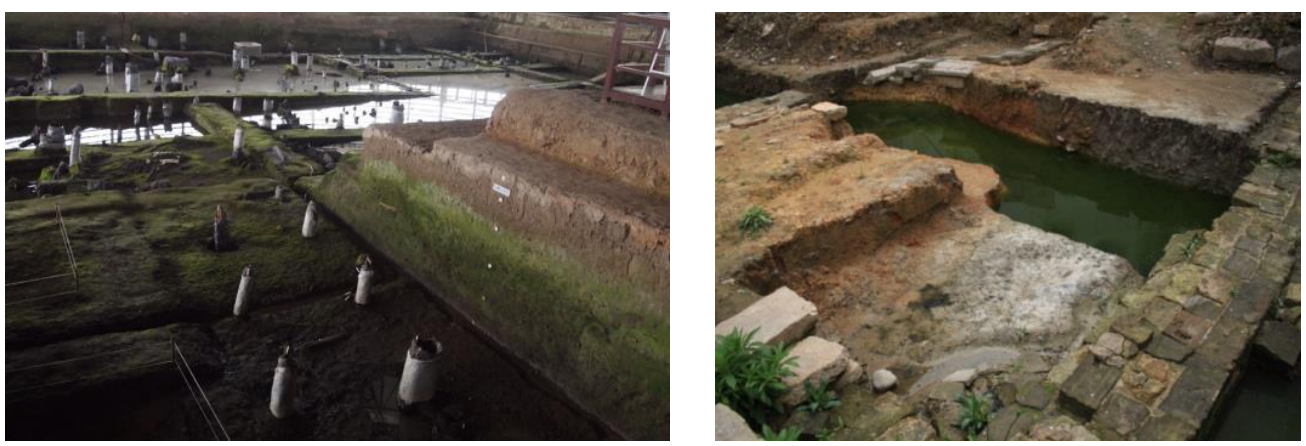

Fig. 1. Soil ruins damaged by microorganisms.

Table 1. Lighting modes in typical ruins' exhibition halls.

\begin{tabular}{ccc}
\hline Group & Lighting modes & Cases \\
\hline 1 & Artificial lighting & $\begin{array}{c}\text {-Hanyang Mausoleum Museum, Xi'an, China } \\
\text {-Hall 1 of Heijo Palace, Nara, Japan } \\
\text {-Zhidanyuan Sluice of Yuan Dynasty, Shanghai, China }\end{array}$ \\
\hline 2 & No lighting & Commonly seen in mural preservation museums \\
\hline 3 & Natural lighting & $\begin{array}{c}\text {-Hall 2 of Heijo Palace, Nara, Japan } \\
\text {-Gulou Front Park, Fuzhou, China }\end{array}$ \\
\hline
\end{tabular}

Soil samples from rammed earth in Wenzhou have been selected for a 56-day experiment. Air Relative Humidity and Lighting Modes are used as experimental variables. Differences in mould growth of six groups under different air RH and lighting conditions have been estimated, using Mould Growth Area Ratio (MGAR) and Mould Growth Grade (MGG) as indicators. The discoveries are promising to provide a theoretical basis and scientific guidance to the environmental controlling and long-term conservation of the damp soil ruins in high-humidity regions.

\section{Materials and methods}

\subsection{Experiment materials}

At the beginning of experiments, samples were maintained at $75 \%-90 \%$ of its saturated moisture content, as the initial level in the ruins while moisture content was kept from $0.30 \mathrm{~kg} / \mathrm{kg}$ to $0.35 \mathrm{~kg} / \mathrm{kg}$. Each sample's area was approximately $28 \mathrm{~cm}^{2}$.

The following devices were used in the experiment: 3D digital microscope (type: KEYENCE, VHX-2000), electronic temperature and humidity recorders (type: T\&D RTR-53A, precision: $\pm 0.1{ }^{\circ} \mathrm{C}$ and $\pm 0.1 \%$ ), highprecision electronic balance (type: Sartorius MSE324S000DU, precision: $\pm 0.1 \%$ ), luminance meter (type: Testo540, precision: \pm 0.1 lux), and anemograph (type: Testo435, precision: $\pm 0.01 \mathrm{~m} / \mathrm{s})$.

\subsection{Experiment methods}

\subsubsection{Environment control}

There are 6 groups of samples kept in sealed drying vessels, with different Lighting Modes (A: with LED lighting, B: dark) and Air Relative Humidity (73\%-92\% / 94\%-97\% / 99.9\%) used as experimental variables. Figure 2 shows the conditions of the samples. Each group consists of three parallel samples. 1A: airtight + artificial lighting, 3 groups of parallel samples with RH range at $73 \%-92 \%, 94 \%-97 \%$ and $99.9 \%, 1 \mathrm{~B}$ : airtight + dark, 3 groups of parallel samples with $\mathrm{RH}$ range at 73\%-92\%, 94\%-97\% and 99.9\%).

To obtain certain air $\mathrm{RH}, \mathrm{NaCl}$ saturated solution, KNO3 saturated solution and pure water were used in sealed dry vessels to generate $73 \%-92 \%, 94 \%-97 \%$ and $99.9 \% \mathrm{RH}$ respectively. The laboratory is closed from the outside and free from the influence of the outside environment, and the internal air temperature was controlled at $24^{\circ} \mathrm{C} \pm 1^{\circ} \mathrm{C}$ by air conditioner, and internal airflow was about $0.01 \mathrm{~m} / \mathrm{s}$.

Temperature and $\mathrm{RH}$ were recorded by electronic temperature and humidity recorders respectively; simultaneously, light intensity and wind speed were recorded by a luminance meter and an anemograph respectively. Table 2 shows the parameters of the six groups of experimental conditions. 
Table 2. Experimental condition of six groups.

\begin{tabular}{|c|c|c|c|c|c|c|}
\hline Group & Lighting mode & Luminance & Temperature & Air RH & Ventilation & Wind speed \\
\hline A & Artificial lighting & $200 \operatorname{lux}$ & \multirow{2}{*}{$24^{\circ} \mathrm{C} \pm 1.5^{\circ} \mathrm{C}$} & \multirow{2}{*}{$\begin{array}{c}\text { A: } 73 \%-92 \% \\
\text { B: } 94 \%-97 \% \\
\text { C: } 99.9 \%\end{array}$} & \multirow{2}{*}{$\begin{array}{c}\text { No } \\
\text { ventilation }\end{array}$} & \multirow{2}{*}{$\begin{array}{c}0 \mathrm{~m} / \mathrm{s} \\
\text { (estimated) }\end{array}$} \\
\hline B & Dark & $0 \operatorname{lux}$ & & & & \\
\hline
\end{tabular}
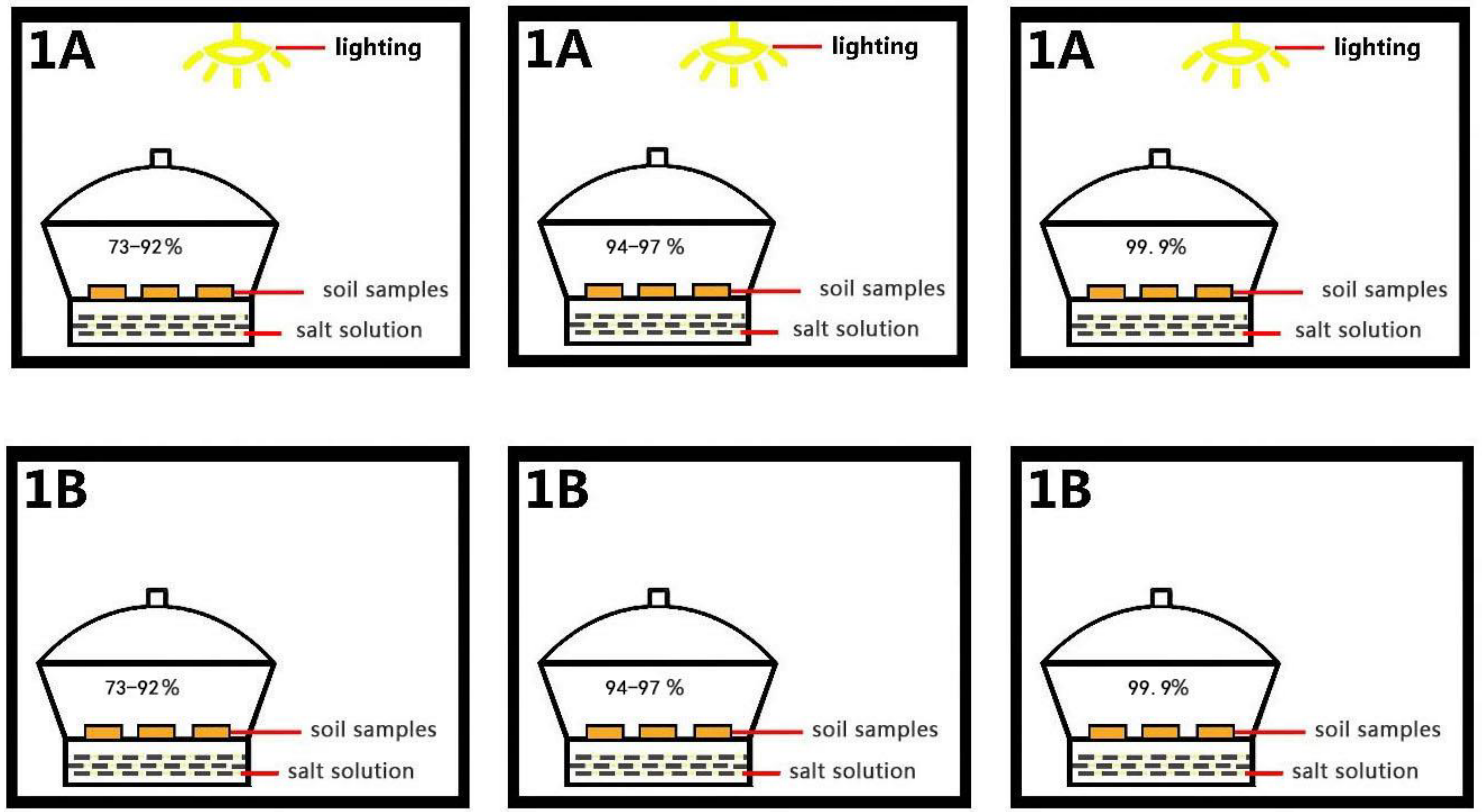

Fig. 2. Schematic diagrams of six conditions in the laboratory (1A: airtight + artificial lighting, 3 groups of parallel samples with RH at three RH, 1B: airtight + dark, 3 groups of parallel samples with RH at three RH).

Table 3. Assessment standard of MGG.

\begin{tabular}{cc}
\hline Grade & Growth characteristics \\
\hline & No mould growth \\
2 & The beginning of mould growth is visible under a microscope. \\
3 & Light mould growth (covering over $10 \%$ of the sample) is visible under a microscope. \\
4 & The beginning of mould growth is visible to the naked eye. \\
5 & Moderate mould growth (covering over $50 \%$ of the sample) is visible to the naked eye. \\
6 & Serious mould growth (covering over 100\% of the sample) is visible to the naked eye. \\
\hline
\end{tabular}

\subsubsection{Assessment indicators of mould growth}

Mould Growth Area Ratio (MGAR) and Mould Growth Grade (MGG) were used as indicators to estimate mould growth level.

Mould Growth Area Ratio (MGAR) is the ratio of the area of mould accounting for the whole area of the visual scope through a microscope in 100 times. Its formula is given as below:

$$
\text { MGAR }=\frac{S_{\mathrm{m}}}{S_{A}} \times 100 \%
$$

where, $\mathrm{S}_{\mathrm{m}}$ is the area of moulds; $\mathrm{S}_{\mathrm{A}}$ is the area of entire observation under a $100 \times$ magnification microscope.

Mould Growth Grade (MGG) indicates the mould growth level [15], and the assessment criteria are listed in Table 3. Due to the non-uniformity of nutrient in rammed reduce the individual differences earth in this case, during the experiment period, mould was observed and evaluated on the selected constant position on the surface of the samples by a 3D digital microscope on a weekly basis. Results were observed and evaluated by the same person to reduce the individual differences. 


\section{Results}

\subsection{Different Mould growth under different RH and lighting conditions}

\subsubsection{Comparison among groups with $\mathrm{RH}$ at $90 \%$}

Figure 3 shows the comparison graph of the evaluation results for the breeding of mould with $\mathrm{RH}$ at $90 \%$ relative humidity in Group A (lighting) and B (dark). The MGAR and MGG in two groups experienced a constant increase in the first month and then decreased.

The first 4-weeks witnessed a constant mould growth in Group A to a maximum at $16 \%$, which was slightly lower than that of group B. The MGAR in group B was slightly larger than that in group B and its decrease lagged behind about two weeks.

The maximum of the MGG in two groups were all Grade 2, which means none of them were visible to naked eyes. Both the mould colonization shrank gradually with their figures went down to Grade 1 in the sixth and seventh week respectively.

In sum, RH at $90 \%$ has limited positive impact on mould growth, while artificial lighting environment is a bit more unfavourable on growth area ratio.

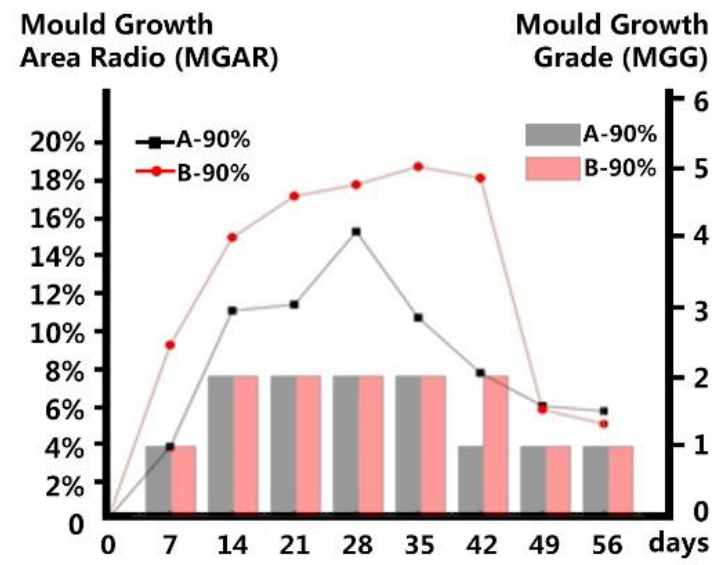

Fig. 3. Comparison of the MGAR and MGG between Group A-90\% and Group B- $90 \%$.

\subsubsection{Comparison among groups with $\mathrm{RH}$ at $95 \%$}

Figure 4 shows the comparison graph of the evaluation results for the breeding of mould with $\mathrm{RH}$ at $95 \%$ relative humidity in Group A (lighting) and B (dark). Two indicators both experienced a constant rise.

The mould in both groups underwent a significant increase especially for the third and fourth week for Group A and B respectively, when their MGAR surged from roughly $20 \%$ to $75 \%$. And then, Mould Growth Area Ratio in group A and B both slowly increased to over $95 \%$ in the following weeks.

Mould Growth Grade of both groups went up to Grade 2 in two weeks, which was achieved by the case with $\mathrm{RH}$ at $90 \%$ in 5 weeks. The figure of group A and B rose to Grade 4 in the fifth and sixth week respectively, which means that more than $10 \%$ mould were evident to naked eye, and then remained stable.

In sum, $\mathrm{RH}$ at $95 \%$ is far more favourable for mould growth compared with RH at $90 \%$.

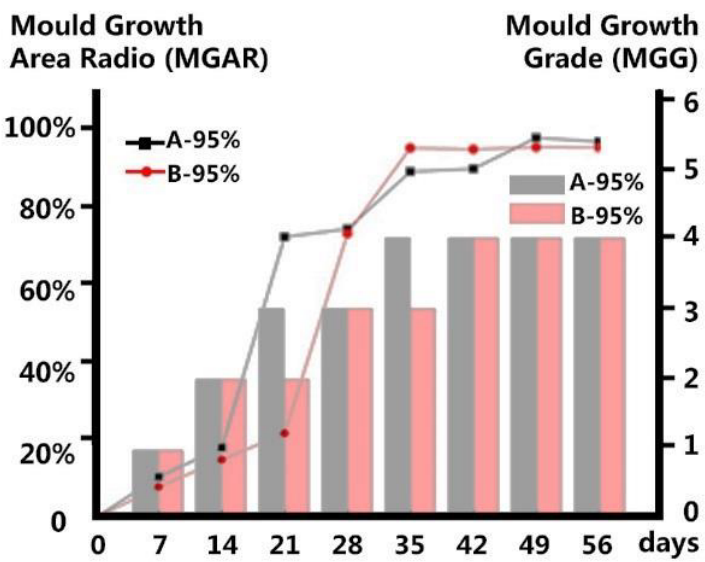

Fig.4. Comparison of the MGAR and MGG between Group A95\% and Group B-95\%.

\subsubsection{Comparison among groups with $\mathrm{RH}$ at $99 \%$}

Figure 5 shows the comparison graph of the evaluation results for the breeding of mould with RH at $99 \%$ relative humidity in Group A (lighting) and B (dark). The mould growth in Group A remained severer than that in Group B.

Mould Growth Area Ratio of both groups experienced a continuous increase to $90 \%$, which was slightly lower than the case with RH at $95 \%$. Mould colonization expanded significantly in the third and sixth week in Group A and B respectively. MGAR of group B lagged behind that of Group A in the first month, and it dramatically surged in the sixth week, outnumbering the figure of Group A.

Mould Growth Grade of Group B remained 1 grade lower than that of Group A, and it increased to Grade 3 before staying at Grade 2 in 1 month.

In sum, $\mathrm{RH}$ at $99 \%$ is less favourable for mould growth compared with $\mathrm{RH}$ at $95 \%$, while the gap is small.

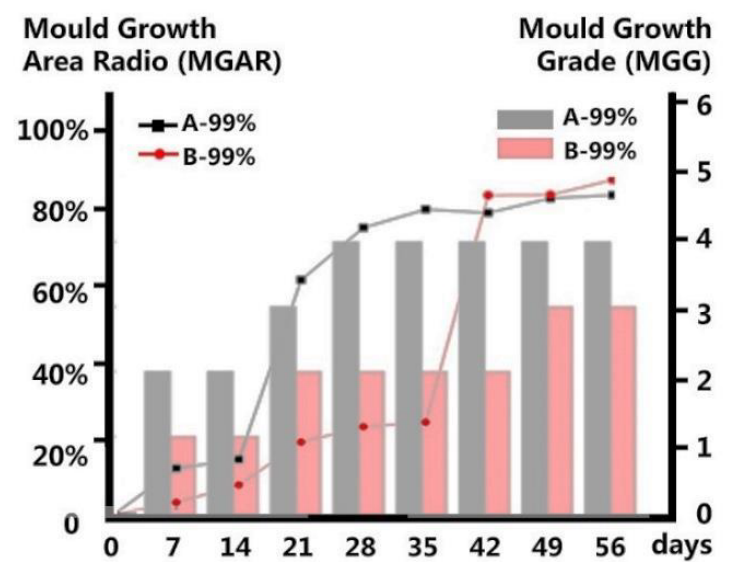

Fig. 5. Comparison of the MGAR and MGG between Group A-99\% and Group B-99\%. 


\subsection{Comparison between Mould Growth and Moisture Content in Group A}

\subsubsection{Comparison among groups with $\mathrm{RH}$ at $90 \%$}

As Figure 6 depicts, moisture content of Group A with $\mathrm{RH}$ at $90 \%$ experienced a continuous decrease. It went done significantly in the first two week while mould growth area increased dramatically.

The first four weeks witnessed the expansion of mould colonization. At the same time, moisture on the surface of the samples decreasing from $0.35 \mathrm{~kg} / \mathrm{kg}$ to $0.15 \mathrm{~kg} / \mathrm{kg}$. Afterwards, MGAR gradually decreased from the peak value of $18 \%$, as moisture content went down to $0.05 \mathrm{~kg} / \mathrm{kg}$ on the 56th day, which means high moisture is greatly related to mould growth.

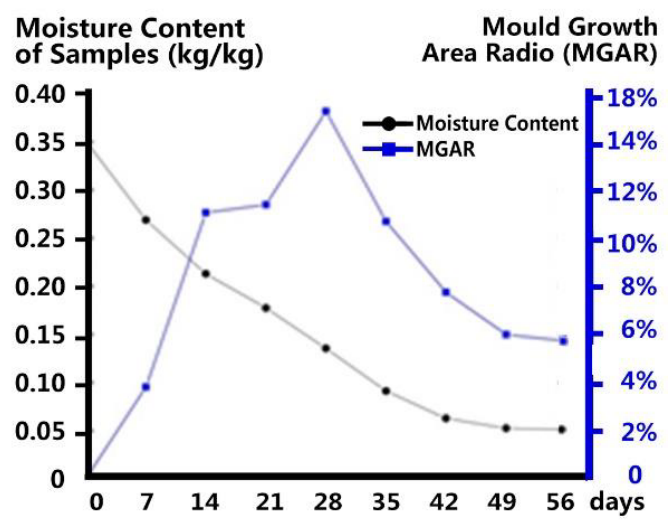

Fig. 6. Moisture content and MGAR with RH at $90 \%$

\subsubsection{Comparison among groups with $\mathrm{RH}$ at $95 \%$}

As Figure 7 depicts, moisture content of Group A with $\mathrm{RH}$ at $95 \%$ also experienced a continuous decrease from $0.37 \mathrm{~kg} / \mathrm{kg}$ to $0.21 \mathrm{~kg} / \mathrm{kg}$, with mould grew significantly in first 3 weeks.

In the following 5 weeks, the increasing speed of MGAR reduced slightly and MGAR reached at $98 \%$ in 56th day. As moisture content of the samples' surface continuously went down, water vapor might be another source for mould growth.

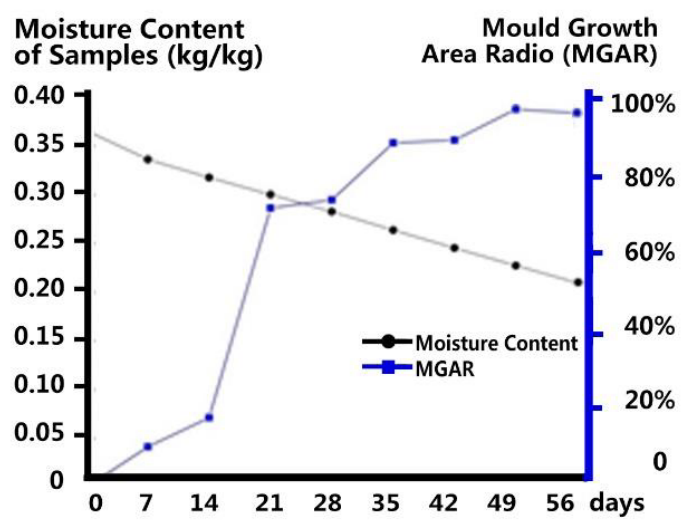

Fig. 7. Moisture content and MGAR with RH at 95\%

\subsubsection{Comparison among groups with $\mathrm{RH}$ at $99 \%$}

As Figure 8 depicts, the decrease of moisture content seemed to be more slowly compared with the case with $\mathrm{RH}$ at $90 \%$ and $95 \%$, roughly from $0.35 \mathrm{~kg} / \mathrm{kg}$ to 0.32 $\mathrm{kg} / \mathrm{kg}$. It means sufficient water vapor could be the main source for mould growth and humid samples' surface provided ideal substrate.

MGAR showed similar trend with the case of RH at $95 \%$ in the first 4 -week period, and its maximum increased to $85 \%$, a bit lower than that of the case with $\mathrm{RH}$ at $95 \%$ (over 95\%). RH at 99\% might be less favourable compared with $95 \%$ especially in the latter half period.

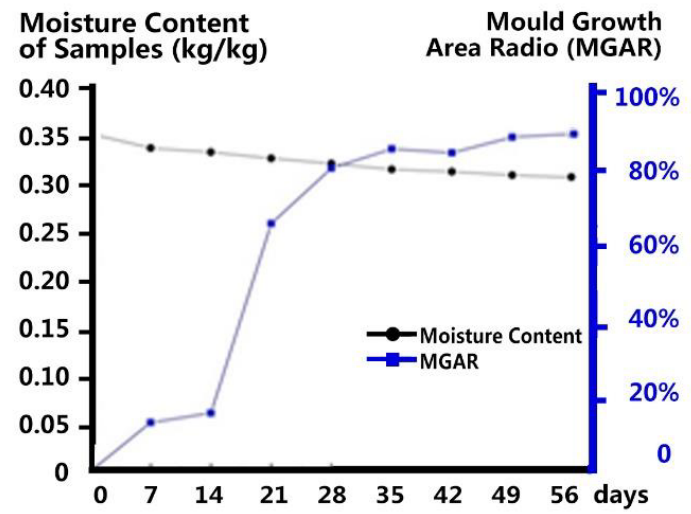

Fig. 8. Moisture content and MGAR with RH at $99 \%$

\section{Discussion}

It is well known that microbial features are intimately intertwined with variables of environments that they inhabit. For this reason, in this case, surfaces of all the samples exhibited different levels of mould growth under different air RH (90\%/95\%/99\%) and lighting conditions (artificial lighting/dark).

Concerning lighting modes, samples with artificial lighting generate more severe mould growth with $\mathrm{RH}$ at $95 \%$ and $99 \%$. One of possible reason is that the availability of light energy can stimulate some phototrophic microorganisms, which serve as the primary producer for the growth. Thus, larger magnitude of stimulated mould growths was observed under lighting condition. In particular, obvious differences between group A (lighting) and B (dark) were seen in the case with $\mathrm{RH}$ at $99 \%$. Mould growth in the dark lagged behind 1-3 weeks than that with artificial lighting conditions. Those with artificial lighting would reach the fast-growing growth period with MGG (at 4) much earlier and even remained higher than the dark case. This finding highlights the ecological importance of light in environments especially originally favouring mould growth.

As to the difference effect of lighting on mould growth, there are some research have proved that light may have different effects on mould growth at different stages [16-18]. At the early stage in our experiment, lighting promoted the colonization of moulds. While at a later stage, the lighting energy may have stimulated 
some phototrophic microorganisms, which serve as the primary producer for the growth of the higher trophic ones. Moreover, it was clearly observed that the inhibition on mould growth in darkness was stronger than that in the artificial lighting, during the first five weeks (Figure 5).

Regarding the case with RH at 90\%, MGAR experienced a continuous decrease after going up to a peak at $15 \%$ while surface moisture content went down significantly, which means moisture in air might not sufficient for continuous mould growth in $90 \% \mathrm{RH}$. Moisture content and MGAR with RH at 95\% and 99\% have little difference, and it should be pointed out that excessive water in the air might be more unfavourable for mould growth since MGAR with RH at $99 \%$ stayed a little lower than that with RH at $95 \%$. So, air RH at $95 \%$ might provide most favourable environment for mould growth. This information implies that there could be an important balance point for surface moisture in context of mould growth. More or less than this balance point, the maximal growth can't be achieved. Namely, the surface moisture plays important roles governing mould growth. This information should be integrated into the model when we try to comprehensively evaluate the mould-driven damages to ruins.

According to some previous studies, oxygen concentration also has a certain impact on mould growth, that is, oxygen concentration must be more than $0.14-0.25 \%$ for the mould growth. It is easy to meet such condition in general situations. But under the condition of RH $99.9 \%$, where the growth of mould is greatly inhibited, it is likely that excessive moisture may form a thin layer of water film on the surface of the sample. This water film may cut off the oxygen supply inhibit and mould growth.

So, we conducted a confirmatory experiment. The observed results of the water film on the sample surface in the confirmatory experiment partially validated our conjecture on the inhibition of mould growth, that is, persistent extreme high humidity (99.9\%) inhibits mould growth.

We have observed this phenomenon in several subterranean tombs, where there are little mould growths in persistently wet areas compared with other highly moist areas. In contrast, since most of the soil ruins in exhibition halls are exposed to the indoor environment, the relative humidity near the surface of the ruins easily becomes close to $95 \%-99.9 \%$, leading to the massive mould growth.

\section{Conclusion}

The conservation of soil ruin exhibition halls is a multifaceted aspect. In this investigation, we initially found that besides other environmental variables influencing on mould growth, the effect of lighting modes and air relative humidity should also be considered. In other words, artificial lighting and sufficient moisture from air ( $\mathrm{RH}$ at around 95\%) serve as crucial favourable conditions for mould growth on surfaces of soil ruins.
Specifically, we found that artificial lighting stimulates the process of mould growth in the first stage (in the first and second week) while this phenomenon gets less obvious in the latter period (from about the sixth week). Therefore, artificial lighting mode in damp soil ruins should be considered more seriously especially in high-humidity regions (around 95\%). In the further research, the effects of individuals in environmental conditions should be discussed to help us to understand this biological process.

For relative humidity, the extremely stable highhumidity environment $(99.9 \%)$ had a significantly inhibitory effect on mould growth of damp surface of soil ruins because the formation of water film may cut off the oxygen supply to mould. When a stable film of liquid water is formed, the mould growth on the surface of ruins will be inhibited. It indicates that keeping air RH at an extreme high level might be a better possible choice for heritage conservation.

However, the humidity fluctuation near damp surface of soil ruins in high humidity region will promote the massive mould growth. RH at $94-97 \%$ provide favourable conditions for mould growth compared with $\mathrm{RH}$ at $73-94 \%$ and $99.9 \%$. In this $\mathrm{RH}$ condition, the mould growth on surface of soil ruin becomes to be visible and begins to grow rapidly to large areas after 3 weeks.

Given that most soil ruins are chronically suffered from stable high relative humidity, it can be a suggestion that remaining air $\mathrm{RH}$ at a saturated relative humidity in dark might be a better choice for soil ruins preservation, especially in dark.

This research was funded by NSFC (No. 51878140), Natural Science Foundation of Jiangsu Province (No. BK20161424) and the Fundamental Research Funds for the Central Universities (3201009202).

\section{References}

1. IEA-Annex 14. (1990) Condensation and energy. Acco, Leuven: Source Book.

2. Sedlbauer K, (2014). Prediction of mould fungus formation on the surface of and inside building components. Dissertation Universitat Stuttgart.

3. Nielsen, K. F, Holm, G, Uttrup, L. P, \& Nielsen, P. A. (2004). Mould growth on building materials under low water activities. influence of humidity and temperature on fungal growth and secondary metabolism. International Biodeterioration \& Biodegradation, 54(4), 325-336.

4. Grant, C, Hunter, C. A, Flannigan, B, \& Bravery, A. F. (2014). The Moisture Requirements of Moulds Isolated from Domestic Dwellings. International Biodeterioration, 25(4), 259-284.

5. Cheng, A., Hsin, Y., \& Lin, W. T., (2014). Effects of mold growth on building materials by different environments in taiwan. KSCE Journal of Civil Engineering, 18(4), 1083-1090.

6. Santos, G.H.D, Mendes, N, \& Philippi, P.C. (2009). 
A building corner model for hygrothermal performance and mould growth risk analyses. International Journal of Heat and Mass Transfer, 52(21-22), 4862-4872.

7. Schabereiter-Gurtner C, Saiz-Jimenez C, Piñar G, Lubitz W, Rölleke S. (2004) Phylogenetic diversity of bacteria associated with Paleolithic paintings and surrounding rock walls in two Spanish caves (Llonin and La Garma). FEMS Microbiol Ecol, 47, pp.235247.

8. B.W. Held, J.A. Jurgens, B.E. Arenz. (2005) Environmental factors influencing microbial growth inside the historic expedition huts of Ross Island, Antarctica. International Biodeterioration \& Biodegradation, 55, pp.45-53.

9. Huang, Z, Zhao, F, Li, Y, Zhang, J, \& Feng, Y. (2017). Variations in the bacterial community compositions at different sites in the tomb of emperor yang of the sui dynasty. Microbiological Research, 196, 26-33.

10. Saiz-Jimenez, Groth, I, \& C. (1999). Actinomycetes in hypogean environments. Geomicrobiology Journal, 16(1), 1-8.

11. Stomeo, F, Portillo, M. C, Gonzalez, J. M, Laiz, L, \& Saiz-Jimenez, C. (2008). Pseudonocardia in white colonizations in two caves with paleolithic paintings. International Biodeterioration \& Biodegradation, 62(4), 483-486.

12. Krakova, L, De Leo, F, Bruno, L, Pangallo, D, \& Urzì, Clara. (2015). Complex bacterial diversity in the white biofilms of the catacombs of st. callixtus in rome evidenced by different investigation strategies. Environmental Microbiology, 17(5), 1738-1752.

13. Yonghui Li, Huarong Xie, Dausuke Ogura, Shi Hu \& QingLing Guo (2016). Quantitative analysis of mold growth differences on surfaces in damp soil ruins affected by ventilation and lighting modes: soil ruin exhibition halls in high-humidity regions. Journal of Asian Architecture and Building Engineering, 15(1), 133-138.

14. Stomp, M., Huisman, J., De Jongh, F., Veraart, A. J., Gerla, D., \& Rijkeboer, M., et al. (2004). Adaptive divergence in pigment composition promotes phytoplankton biodiversity. Nature (London), 432(7013), 104-107.

15. Viitanen. H, Hanhijarvi. A, Hukka. A, et al. (2000) Modeling mould growth and decay damages. Proceedings of Healthy Buildings, 3, pp.341-346.

16. P. Sanmartín, D. Vázquez-Nion, J. Arines, L. CaboDomínguez, B. Prieto, Controlling growth and colour of phototrophs by using simple and inexpensive coloured lighting: A preliminary study in the Light4Heritage project towards future strategies for outdoor illumination, Int. Biodeterior. Biodegrad. 122 (2017)107-115.

17. C.A. Crispim, C.C. Gaylarde, Cyanobacteria and biodeterioration of cultural heritage: A review, Microb. Ecol. 49 (2005) 1-9.
18. C. Saiz-Jimenez, P. Albertano, D. Moscone, G. Palleschi, B. Hermosin, C. Saiz-Jimenez, S. Sanchez-Moral, M. Hernandez-Marine, C. Urzì, I. Groth, V. Schroeckh, M. Saarela, T. MattilaSandholm, J.R. Gallon, F. Graziottin, F. Bisconti, R. Giuliani, Cyanobacteria attack rocks (CATS): Control and preventive strategies to avoid damage caused by cyanobacteria and associated microorganisms in Roman hypogean monuments, in: Mol. Biol. Cult. Herit., (2019) 151-162. 